\title{
IMPLIKASI RELIGIUSITAS, GAYA HIDUP HEDONIS, DAN GAJI TERHADAP KETAHANAN KELUARGA
}

\author{
R. Tanzil Fawaiq Sayyaf ${ }^{1}$, \\ R. Iqbal Robbie ${ }^{2}$ \\ ${ }^{1}$ Fakultas Agama Islam, Universitas Muhammadiyah Malang \\ Email: tanzil_fawaiq@umm.ac.id \\ ${ }^{2}$ Fakultas Ekonomi dan Bisnis, Universitas Muhammadiyah Malang \\ Email : iqbal_robbie@umm.ac.id
}

\begin{abstract}
ABSTRAK
Keluarga sebagai sistem sosial terkecil memiliki peran penting dalam mewujudkan kesejahteraan penduduk yang merupakan cita-cita pembangunan. Keluarga menjadi lingkungan sosial pertama yang mengenalkan cinta, moralitas agama, sosial budaya dan sebagainya. Penelitian ini ingin mendeskripsikan pengaruh religiusitas, gaya hidup hedonis dan gaji terhadap ketahanan keluarga. Untuk mencapai tujuan ini, pendekatan kualitatif digunakan dengan beberapa informan yang dipandang layak menjawab pertanyaan tentang penelitian ini, selanjutnya dilakukan Focus Group Discussion (FGD) atau artikel ini menyebut sebagai diskusi sejawat. Hasil penelitian ini menjawab beberapa pertanyaan penting bagaimana religiusitas, gaya hidup dan gaji mempunyai implikasi terhadap ketahanan keluarga. Pertama, kualitas religiusitas seseorang berdampak signifikan terhadap ketahanan keluarga, selain itu, pengaruh gaya hidup hedonis sangat berimplikasi gaya hidup. Sikap hedonis cenderung menyebabkan penggunaan sesuatu secara tidak tepat atau berlebihan, atau dalam bahasa agama disebut sebagai sikap tabzir, dan tabzir cenderung merusak tatanan yang ada. Bahwa stabilitas ekonomi juga mempengaruhi ketahanan keluarga.
\end{abstract}

Kata kunci: religiusitas, hedonis, gaji, ketahanan keluarga

\section{PENDAHULUAN}

Pembahasan tentang ketahanan keluarga tidak akan terlepas dari permasalahan-permasalahan yang ada dalam keluarga. Keluarga merupakan sebuah keutuhan dari berbagai sistem yang menyatukan. Keluarga yang baik akan mengahasilkan pola pikir, pola bertindak yang baik. Keluarga yang dididik dalam naungan agama yang baik akan menghasilkan kemaslahatan yang baik pula bagi kehidupan manusia. Laki-laki sebagai pemimpin, penanggung jawab dalam keluarga yang dilebihkan oleh Allah bagiannya sedikit dari yang dimiliki oleh perempuan. Laki-laki dan perempuan memiliki keistimewaan, dan masing-masingnya diberikan kelebihan oleh Allah.

Beberapa kasus yang terjadi saat ini khususnya masalah korupsi di perusahaan dan lembaga publik berdampak kepada kinerja perusahaan dan karyawan. Kasus tersebut terjadi karena ada kelonggaran pengawasan mengenai standar operasional perusahaan, meskipun saat ini beberapa perusahaan membangun sebuah sistem yang solid seperti dijelaskan dalam sebuah survei yang dilakukan pada tahun 2010 di Inggris dan beberapa perusahaan di benua Eropa, terungkap bahwa masalah-masalah yang sedang ramai dibicarakan terhadap organisasi adalah suap, korupsi dan fasilitasi pembayaran, mengenai diskriminasi, pelecehan atau intimidasi (Wheldon \& Webley, 2013) Sekarang ini hampir tidak ada perusahaan yang aman dari kecurangan, salah satu pembahasan yang utama adalah kurangnya etika, baik etika perusahaan maupun etika pemimpinnya. Apalagi dengan lingkungan yang semakin kompleks sehingga menyebabkan pengaruh baik atau pengaruh buruk yang semakin besar, kepemimpinan yang efektif dapat dicapai dengan memperkuat karakteristik pemimpin dan memperkuat perilaku etis, karena dengan etika yang kuat akan mempengaruhi, membantu pemimpin dalam mengendalikan supremasi perusahaan.

Dalam penelitian ini, permasalahan utamanya adalah bagaimana karyawan merasakan ketahanan keluarga karena keluarga merupakan faktor penting didalam menjaga kualitas kehidupan. Hal ini tentunya akan dipengaruhi berbagai faktor seperti tingkat religiusitas seseorang dan gaya hidup hedonis yang belakangan ini semakin menjamur di masyarakat. Obyek penelitian adalah karyawan UMM yang identik dengan nilai keislaman. 
Locus penelitian dipilihlah Universitas Muhammadiyah Malang, merupakan Universitas swasta terbesar di Kota Malang, dan tergabung dalam Perguruan Tinggi Muhammadiyah dibawah naungan Pengurus Pusat Muhammadiyah. UMM mempunyai 13 Fakultas yang terdiri dari tingkat sarjana dan Pasca sarjana, UMM juga mempunyai akreditasi unggul dalam lingkup Universitas di Jawa Timur. Hal ini termasuk dalam fasilitas penunjang pendidikan dan sarana prasarana mempunyai kualitas yang terbaik.

Universitas Muhammadiyah Malang (UMM) menyediakan kenyamanan dalam iklim pembelajaran. Sebagai Kota besar kedua di Jatim, kota ini memiliki berbagai macam kampus baik kampus teknologi, entrepreuneurship, dan heritage. Dalam situasi kampus mudah ditemukan area mahasiswa dalam melakukan diskusi, kajian, case study hingga kuliner. Selain mahasiswa dalam negeri, Malang juga menjadi tujuan belajar bagi mahasiswa asing. Berdiri mulai tahun 1964, UMM tumbuh dan berkembang mengantarkan mahasiswa menjadi manusia yang unggul dalam iman da takwa. Tidak ada prestasi yang tidak dihargai menjadikan UMM siap mencetak leader yang kompeten untuk berkarya dan mengabdi di berbagai sektor. Berdasarkan penjelasan ini, UMM masih mempunyai tanggung jawab yang besar dan masih ada kekurangan dalam hal peningkatan status menjadi universitas yang diakui di Asia dan in sangat akan dipengaruhi oleh ketahanan keluarga dari karyawan UMM tersebut. Penelitian ini mengambil objek di Fakultas yang berlokasi di Gedung Kuliah Bersama (GKB) 2 Universitas Muhammadiyah Malang sebagai cerminan bagaimana faktor religiusitas, gaya hidup hedonis karyawan yang ada akan mempengaruhi ketahanan keluarga. Karena terdapat salah satu fakultas yang ada di sudut gedung ini yaitu Fakultas Agama Islam yang bisa merepresentasikan nilainilai ke-Islaman yang ada di Universitas Muhammadiyah Malang ini.

Dengan latar belakang diatas, penulis ingin menguji tujuan permasalahan tersebut dengan jenis pendekatan kualitatif, penelitian ini ingin menjawab bagaimana religiusitas, gaya hidup dan gaji memberikan implikasi dalam ketahanan keluarga. Beberapa penulis sudah menulis isu-su tersebut, akan tetapi fokus Penelitian ini belum menjadi perhatian sehingga menjadi research gap dan penelitian ini merupakan langkah awal untuk menelusuri permasalahan tersebut.

Dengan demikian, argumentasi sementara artikel ini, bahwa pertama, kualitas religiusitas seseorang begitu berpengaruh terhadap ketahanan keluarga. Selanjutnya, bahwa pengaruh gaya hidup hedonis sangat mempengaruhi gaya hidup. Berlebihan bertentangan dengan iman, akhlak yang baik (Ihsan), dan amal saleh. Sikap Hedonis cenderung menimbulkan penggunaan sesuatu tidak pada tempatnya atau berlebihan, atau dalam bahasa agama disebut sebagai sikap tabzir, dan tabzir cenderung merusak tatanan yang ada. bahwa kemapanan ekonomi juga mempengaruhi ketahanan keluarga. Tapi, sikap sabar, qanaah, kebersamaan, dan sikap mengelola keinginan dengan baik, biasanya dapat mengendalikan ketahanan keluarga meski dengan gaji yang terbilang kecil.

\section{TINJAUAN PUSTAKA DAN HIPOTESIS Konsep Religiusitas}

(Allport \& Ross, 1967) menunjukkan konsep mengenai religiusitas, yaitu ada dua type : orientasi religius secara ekstrinsik dan orientasi religius secara intrinsik. Sedangkan dalam agama Islam dikenal sebutan iman atau akidah dan syariah, ibadah atau ritual, ilmu pengetahuan (termasuk teologi, filsafat dan hukum), ihsan, dan amal atau ta'aawanu 'ala al-Birri wa al-Taqwa (kemanusiaan/tolong menolong).

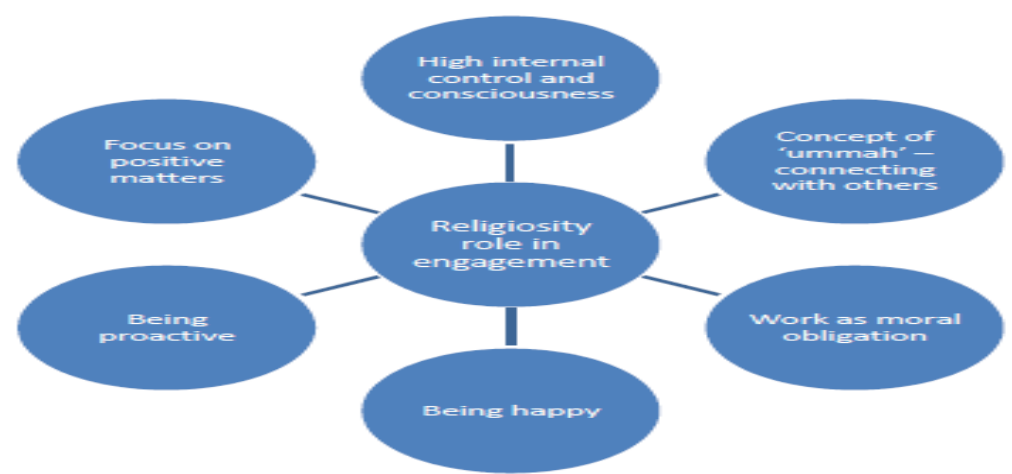

Gambar 1 : Konsep Religiusitas 
Orientasi religius secara ekstrinsik adalah bentuk religius seseorang yang menunjukkan kerjasama atau afiliasi dengan orang lain. Sedangkan Orientasi religius secara intrinsik adalah bentuk religius seseorang yang mencari kesempurnaan untuk amalan diri sendiri. Dalam orientasi secara ekstrinsik menunjukkan afiliasi dengan orang lain, sehingga nanti akan diketahui bagaimana pengaruh Kepemimpinan terhadap Komitmen karyawan (Riaz et al., 2016)

(King \& Boyatzis, 2016) menyebutkan ada perbedaan antara religiusitas dengan spiritualitas. Beberapa penelitian membuktikan religiusitas dan spiritualitas mempunyai dampak positif pada perilaku dan sikap seseorang. Internalisasi nilai-nilai agama mempengaruhi etika dalam perilaku (Mitroff \& Denton, 2001). Spiritualitas berpengaruh terhadap kinerja karyawan (Singh et al., 2017), kebutuhan akan pencapaian, kebutuhan akan kekuasaan dan kebutuhan akan afiliasi (Sulistyo \& Wijayanto, 2015) Religiusitas mengajarkan kesetiaan, rasa tanggung jawab, tanggung jawab, dan secara umum seperangkat nilai yang membuat individu berkomitmen terhadap pekerjaan mereka. Akibatnya, individu yang sangat religius (dengan tingkat motivasi intrinsik yang tinggi) memiliki pengertian moral yang tinggi dan cenderung mengadopsi sikap, perilaku, dan keputusan berdasarkan nilai moral mereka. Akibatnya, mereka lebih cenderung bisa mengendalikan perilaku secara moral terhadap gaya hidup mereka dan memberi nilai signifikan pada penghargaan dan manfaat spiritual.

\section{Religiusitas dengan Kepemimpinan Etis dalam Islam}

Islam memiliki kode etik perilaku, seperangkat aturan dan prinsip etika yang mendorong muslim untuk bertindak secara moral. Islam menekankan penghormatan prinsip-prinsip moral dalam semua aspek kehidupan manusia. Dalam agama islam, kepatuhan terhadap kode moral dan perilaku etis adalah bagian dari iman. Selain itu, (Abeng, 2006) menegaskan bahwa Islam menuntut kepatuhan yang ketat terhadap ajaran moral Alquran. Muslim juga didesak untuk tidak menyinggung atau menyakiti orang lain. Oleh karena itu, ketaatan yang ketat terhadap tradisi agama islam akan memperkuat norma moral dan kode etik dalam sistem etika individu.

\section{Gaya Hidup Hedonis}

Gaya hidup adalah pola hidup seseorang dala mengekspresikan minat, karakter, aktifitas maupun perilaku seseorang. Hal ini digambarkan bagaimana adaptasi seseorang untuk berinteraksi dengan masyarakat maupun lingkungannya (Kaparang, 2013). Ada literatur lain yang dikemukakan (Trimartati, 2014) hedonisme merupakan tujuan hidup seseorang yang ujungnya adalah mendapatkan kesenangan dan kenikmatan semata. Jadi kesimpulannya adalah hedonisme merupakan gaya seseorang dalam mencari kesenangan dan itu merupakan tujuan hidupnya. Saat ini, terjadi fenomena yang sudah umum di masyarakat yakni perilaku yang ingin bergaya bebas, lebih foya-foya dalam penampilan, selalu mengutamakan materi (Sudarsih, 2018) Perubahan sikap perilaku dan konsumerisme menjadi hal yang tidak bisa disepelekan, karena gaya-gaya seperti itu yang akan mempengaruhi pendapatan dan tingkat kemapanan sebuah keluarga. Menurut Saputri dalam (Salam, 2000) gaya hidup yang hedonis mempunyai prinsip segala hal yang dilakukan akan berakibat baik asalkan kesenangan dan kenikmatan didapatkan.

Status tersebut bukan hanya didominasi kalangan anak muda, tetapi juga akibat pengaruh keluarga yang mengutamakan kemapanan materi sehingga kualitas hidup perlu dipertanyakan. Remaja saat ini lebih suka menggunakan uangnya untuk kebutuhan yang sifatnya tersier, sedangkan kebutuhan primernya tidak begitu diperhatikan. Menurut (Sari, 2018) hedonisme dapat membuat kebutuhan seseorang hanya dilatarbelakangi adanya keinginan untuk terlihat cantik dan tidak ketinggalan zaman. Ada yang suka mencari perhatian, impulsif, mudah ikut trend teman, dan senang mengisi waktu luang di luar rumah. Perilaku hedonisme mempunyai dampak terhadap keluarganya yang memicu hal negatif dan berujung kepada tanggapan masyarakat yang negatif seperti pencemaran nama baik keluarga, perilaku yang tidak sesuai harapan keluarga serta citra negatif di masyarakat (Purwanti et al., 2014).

\section{Tingkat Gaji}

Menurut istilah dalam perekonomian, gaji dan upah merupakan bentuk kompensasi langsung yang wajib diterima oleh seluruh karyawan atas hasil kerjanya. Menurut (As'ad, 2013) gaji adalah kepastian uang yang diterima dan waktu penerimaannya selalu tepat, misalnya setiap akhir bulan seorang karyawan akan menerima hak setelah melakukan karyanya, ada juga yang mengistilahkan upah yaitu 
sejumlah uang yang diterima karyawan tetapi nilai dan waktunya tidak bisa ditentukan. Jadi disini mencoba menjelaskan perbedaan gaji dan upah adalah waktu dan nilai hak yang didapatkan.

Berikut siklus penggajian dari perusahaan yang diambil dari (Swastha \& Irawan, 2005) yaitu :

1. Prosedur kehadiran dan timelines. Maksudnya adalah bertujuan untuk mengontrol waktu kehadiran dan jumlah waktu kerja karyawan sebagai dasar perhitungan gajinya.

2. Daftar gaji dan upah. Fungsi dalam hal ini adalah membuat daftar keseluruhan gaji dan pengupahan karyawan.

3. Pembayaran gaji dan upah. Dalam hal ini melibatkan divisi pencatatan piutang atau utang dan bagaimana mekanisme pembayaran gaji dan upah.

4. Pelaksanaan distribusi. Dalam pelaksanaan distribusi gaji dan upah, departemen yang bertanggung jawab yang akan melaksanaan pembayaran tersebut.

Menurut (Mas'ud, 2004) salah satu ukuran gaji diukur menggunakan indikator: jumlah gaji, besar tunjangan, dan tambahan insentif.

\section{Ketahanan Keluarga}

Pembahasan tentang ketahanan keluarga tidak akan terlepas dari permasalahan-permasalahan yang ada dalam keluarga. Keluarga merupakan sebuah keutuhan dari berbagai sistem yang menyatukan. Keluarga yang baik akan mengahasilkan pola pikir, pola bertindak yang baik. Keluarga yang dididik dalam naungan agama yang baik akan menghasilkan kemaslahatan yang baik pula bagi kehidupan manusia. Keluarga merupakan sebuah sistem. Penyebutan sistem ini dikarenakan terjadi komunikasi dua arah yang berulang (suami-istri) dan komunikasi segala arah bagi seluruh anggota keluarga. Oleh karena itu, setiap komponen dalam sistem ini berfungsi saling menguatkan, mengarahkan, membina dan memberikan perhatian serta kasih sayang kepada setiap anggota dalam keluarga menurut (Lubis, 2018)

Dalam KBBI dijelaskan bahwa Ketahanan (fisik, hati) mendefinisikan bahwa ketahanan adalah kesabaran, kekuatan, ketulusan hati. Ketahanan keluarga diartikan bahwa keluarga mampu bersabar, mampu menahan dan kuat dalam fisik dan psikisnya. Ketahanan keluarga harus mampu mengembangkan potensi dalam keluarganya sehingga mampu meraih kesejahteraan dalam berkehidupan.

Untuk merealisasikan ketahanan keluarga diperlukan adanya hamonisasi antara fungsi, peran dan tugas masing-masing anggota keluarga tersebut. Di antaranya adalah sebagai berikut:

1. Pemeliharaan kebutuhan fisik keluarga;

2. Alokasi sumber daya keluarga;

3. Pembagian tugas di antara seluruh anggota keluarga;

4. Sosialisasi anggota keluarga;

5. Reproduksi, penambahan dan pelepasan anggota keluarga;

6. Pemeliharaan tata tertib;

7. Penempatan anggota di masyarakat;

8. Pemeliharaan moral dan motivasi.

\section{METODE PENELITIAN}

Penelitian ini memanfaatkan Pendekatan penelitian yang digunakan adalah studi lapang (field research). Data diolah dengan menggunakan metode deskriptif kualitatif, yaitu mengolah data berdasarkan nilai yang terkandung dalam setiap data. Perolehan informasi dari penelitian terdahulu penting untuk diperhatikan, tanpa memperdulikan apakah sebuah penelitian menggunakan data primer atau sekunder. Penelusuran literatur merupakan data sekunder yang dikumpulkan melalui referensi berupa buku dan jurnal yang ada serta ditelaah secara tekun merupakan kerja kepustakaan yang sangat diperlukan dalam penelitian. Untuk data primer diperoleh melalui teknik pengumpulan data dilakukan dengan cara metode wawancara secara mendalam kepada informan-informan yang dinilai layak menjawab beberapa pertanyaan pemandu. Kemudian, setelah dipilih beberapa informan yang dipandang layak menjawab pertanyaan tentang penelitian ini, selanjutnya dilakukan Focus Group Discussion (FGD) atau artikel ini menyebut sebagai diskusi sejawat. Segala data yang ada dielaborasi secara intelektual dengan berbagai dokumen pendukung dan teori, sehingga dapat ditentukan kesimpulan tertentu yang dapat menjawab pertanyaan yang diajukan dalam artikel ini. 


\section{HASIL DAN PEMBAHASAN}

Ketahanan keluarga diartikan bahwa keluarga mampu bersabar, mampu menahan dan kuat dalam fisik dan psikisnya. Ketahanan keluarga harus mampu mengembangkan potensi dalam keluarganya sehingga mampu meraih kesejahteraan dalam berkehidupan. Peneliti menemukan bahwa membentuk ketahanan keluarga diperlukan adanya hamonisasi antara fungsi, peran dan tugas masing-masing anggota keluarga tersebut. Di antaranya adalah sebagai berikut:

1. Pemeliharaan kebutuhan fisik keluarga;

Salah satu informan menyatakan bahwa Ketahanan keluarga adalah cara/ide terkait bagaimana keluarga menghadapi realita dalam mengarungi perjalanan Rumah tangga baik dr aspek penanaman agama, dan kesejahteraan ekonomi

2. Alokasi sumber daya keluarga;

Kondisi keluarga dalam mengelola sumber daya baik fisik maupun non fisik serta dalam mengelola permasalahan yang dihadapi keluarga tersrbut, serta bagaimana mencapai tujuan keluarga yang berkualitas

3. Pembagian tugas di antara seluruh anggota keluarga

Seorang ayah mempunyai tanggung jawab sebagai pemimpin rumah tangga, bertugas untuk menjamin ketahanan keluarga itu tercapai.

4. Sosialisasi anggota keluarga;

Bagaimana membina keluarga dengan baik di bawah sinaran cahaya Al-Qur'an dan Sunnah sehingga terwujud keluarga yang sakinah, mawaddah wa rahmah

5. Reproduksi, penambahan dan pelepasan anggota keluarga;

6. Pemeliharaan tata tertib

Ketahanan keluarga diantaranya memiliki makna sebagai bentuk perlindungan internal keluarga dari gangguan luar yang bersifat fisik maupun non-fisik, pola penanaman pendidikan dan pengasuhan bagi anggota keluarga guna mewujudkan dan menanamkan nilai-nilai moral dan religiusitas. Religiusitas mengajarkan kesetiaan, rasa tanggung jawab, tanggung jawab, dan secara umum seperangkat nilai yang membuat individu berkomitmen terhadap pekerjaan mereka. Akibatnya, individu yang sangat religius (dengan tingkat motivasi intrinsik yang tinggi) memiliki pengertian moral yang tinggi dan cenderung mengadopsi sikap, perilaku, dan keputusan berdasarkan nilai moral mereka. Akibatnya, mereka lebih cenderung bisa mengendalikan perilaku secara moral terhadap gaya hidup mereka dan memberi nilai signifikan pada penghargaan dan manfaat spiritual. Religiusitas bukan sekedar rajin mengerjakan ritual keagamaan, namun praksis akhlak yang karimah, bagian yang menyatu dalam membina rumah tangga karena seseorang yang memiliki religiusitas yang baik, maka ia akan "menghadirkan" Allah dalam kehidupannya. Artinya ia akan berupaya meneladani sifat-sifat Allah untuk diterapkan di dalam keluarganya.

Religiusitas yang dimaksud bukanlah praktik ritual ibadah belaka. Namun, jauh lebih dari itu adalah memahami makna dari ibadah ritual maupun aktifitas lainnya yang mengutamakan sifat ilahiah dalam membentuk ketahanan keluarga. Religiusitas sangat penting, namun berpengaruh dan tidaknya tergantung kepada kualitas panutan dalam keluarga, anggota keluarga juga lingkungan dimana keluarga itu tinggal. layaknya sebuah pernyataan yang umum ditelinga kita "Agama itu benar dan tidak salah, yang terkadang tidak benar atau kadang salah ialah orang yang menjalankan agamanya". Religiusitas sangat menentukan karena hal ini menjadi titik awal, panduan perjalanan, sekaligus tujuan hidup berkeluarga. Juga solusi atas permasalahan-permasalahan yang terjadi.

Agama diterapkan tidak hanya ektrensik namun juga intrinsik (meminjam istilah jalaludin rakhmad), Islam adalah panduan. Selama mengikuti buku petunjuk dengan benar, maka kemungkinan untuk selamat semakin besar. Namun demikian, Islam juga merupakan solusi. solusi itu sendiri tidak harus mempertahankan bagian tubuh yg tidak bisa diobati, membusuk dan membahayakan organ-organ yg masih sehat. Adakalanya talak menjadi solusi sebagaimana amputasi dalam bidang medis. Tanpa iman, akhlak dan amal saleh, kiranya manusia akan kesulitan berhubungan sosial dengan sesama, terutama dalam lingkungan keluarga sebab orang yang bertuhan, akan berpikir postif dan tidak akan gampang putus asa dalam menghadapi hidup. Secara fisik setiap hari rajin shalat dan menjaga kebersihan. secara fikiran selalu bersikap positif, adil dan terbuka. Secara psikis menghormati yang tua dan menyayangi yg muda. 
Keselarasan antara iman, akhlak dan amal saleh dalam kehidupan sehari-hari. Namun hal ini tdak bisa dikuantifikasi maupun dikualifikasikan oleh satu orang terhadap orang lain. Hal ini adalah gambaran hubungan antara seorang hamba dengan Tuhannya. Religius yang saya maksud bukanlah orang yang terlihat rajin melakukan praktik ritual ibadah (mahdhah khususnya) belaka. Namun jauh lebih dari itu adalah memahami makna dari ibadah ritual maupun aktifitas lainnya yang bernilai ibadah sehingga ia berupaya melakukan dan memberikan yang terbaik bagi. Artinya, setiap aktifitas yang ia lakukan adalah dalam rangka ibadah. Puncaknya adalah ihsan yaitu memberikan kebaikan kepada yang lain.

Religi berarti agama, aspek religiusitas dalam kacamata dhohir adalah tingkat ketaatan dan kepatuhan terhadap aturan main agama, adapun dalam aspek batin menjadi hak prerogatif pembuatan aturan arena agama mengajari kita untuk memperbanyak silaturahmi. Juga memuliakan tetangga dan tamu. Orang yang memegang prinsip religiusitas hakiki akan memiliki sikap hidup yang toleran, terbuka, mengedepankan persamaan daripada perbedaan sesuai dengan nilai atau pedoman itu sendiri.

\section{Hedonis dalam kehidupan keluarga}

Ada 2 faktor pengaruh hedonis ini, yakni faktor intrinsik individu baik pengalaman maupun karakter, sedangkan faktor berikutnya yaitu faktor ekstrinsik seperti pengaruh lingkungan atau keluarga sendiri (Trimartati, 2014). Menurut (purwo Saputro \& Handayani, 2016) gaya hidup seseorang akan mengalami perubahan yang signifikan teriring perkembangan zaman hal ini bisa dilihat dari tingkat belanja atau konsumsi yang semakin besar.

Hedonis ialah kehidupan yang materialistik, segala sesuatu dinilai dengan kesengan duniawi segala hal yang berlebihan dalam harta dan gaya hidup. Dikecam di dalam QS AlTakatsur. Sikap berlebihan dalam mengkonsumsi sesuatu, menggunakan sesuatu tidak sesuai dengan porsinya, Pandangan yg menganggap materi itu adalah tujuan hidup tentu berpengaruh, gaya hidup hedonis biasanya diukur dgn banyaknya materi, sehingga ketika materi tidak cukup, dapat mempengaruhi ketahanan keluarga. Karena sudah melawan buku panduan, maka pasti akan ketemu masalah berat dan kompleks, meskipun tidak segera. Tapi pasti akan datang.

Hedonis mempengaruhi gaya hidup. Berlebihan bertentangan dengan iman, akhlak yang baik (Ihsan), dan amal saleh. Sikap Hedonis cenderung menimbulkan penggunaan sesuatu tidak pada tempatnya atau berlebihan. dalam bahasa agama disebut sebagai sikap tabzir, dan tabzir cenderung merusak tatanan yang ada. Tabzir berlaku diberbagai macam aspek; waktu, pembicaraan penuh dengan ghibah, sindiran ataupun fitnah, layaknya kisah bu Tejo yang sedang viral, harta, ilmu, kedudukan dan lain sebagainya. Karena kemapanan ekonomi juga mempengaruhi ketahanan keluarga. Tapi, sikap sabar, qanaah, kebersamaan, dan sikap mengelola keinginan dengan baik, biasanya dapat mengendalikan ketahanan keluarga meski dengan gaji yang terbilang kecil.

\section{Gaji mempengaruhi pola pikir keluarga}

Menurut penelitian (Dekoulou \& Trivellas, 2015) dari sudut pandang ekonomi sangat berpengaruh, berpengaruh menjadi Tantangan untuk maju atau bisa juga menjadi hambatan bagi keluarga untuk bisa mandiri dan maju sebab untuk hidup berkualitas dan dapat bertahan hidup dg baik, sezeorang membutuhkan asupan gizi dan pendidikan. Ini sesuai dengan temuan penelitian ini bahwa tantangan keluarga pasti membutuhkan dana yg cukup yang pertama memang faktor religiusitas keluarga, kedua faktor ekonomi dan yang ketiga, faktor cinta dan setia. Kebiasaan dalam berlaku bijaksana, welas asih dan suka bekerjasama (kolaborasi) sangat mempengaruhi keharmonisan rumah tangga salah satu faktor munculnya sifat hedonis; 1) Media sosial jika tidak dikelola dengan baik; 2) Kedekatan berlebihan dengan lawan jenis yang bukan pasangan hidupnya yang sah; 3) Menikah dalam usia muda dengan bekal ilmu berkeluarga yang tidak cukup.

\section{KESIMPULAN DAN SARAN}

Terdapat beberapa temuan penting dalam artikel ini, yakni, pertama, bahwa kualitas religiusitas seseorang begitu berpengaruh terhadap ketahanan keluarga. Hal ini dkarenakan, bahwa Allah memberi kelebihan kepada laki-laki dan perempuan untuk memaksimalkan potensi yang ada ada pada dirinya. Laki-laki diberikan potensi menjadi pemimpin di dalam rumah tangga. Ia bertugas sebagai terdepan dalam mempertahankan ketahanan keluarga dari segala macam 
rintangan. Sedangkan wanita, ia sebagai penyeimbang laki-laki dalam tugasnya sebagai penjaga keutuhan sistem dalam ketahanan keluarga. Selanjutnya, temuan penting yang lain adalah, bahwa pengaruh gaya hidup hedonis sangat mempengaruhi gaya hidup. Berlebihan bertentangan dengan iman, akhlak yang baik (Ihsan), dan amal saleh. Sikap Hedonis cenderung menimbulkan penggunaan sesuatu tidak pada tempatnya atau berlebihan, atau dalam bahasa agama disebut sebagai sikap tabzir, dan tabzir cenderung merusak tatanan yang ada. Tabzir berlaku diberbagai macam aspek; waktu, pembicaraan penuh dengan ghibah, sindiran ataupun fitnah, layaknya kisah bu Tejo yang sedang viral, harta, ilmu, kedudukan dan lain sebagainya. Kemudian, artikel ini berargumentasi bahwa kemapanan ekonomi juga mempengaruhi ketahanan keluarga. Tapi, sikap sabar, qanaah, kebersamaan, dan sikap mengelola keinginan dengan baik, biasanya dapat mengendalikan ketahanan keluarga meski dengan gaji yang terbilang kecil.

Sebagai refleksi intelektual dan saran atas hasil penelitian ini, secara Teoritis bahwa dalam mempertahankan keharmonisan keluarga hendaknya dilakukan bersama oleh seluruh elemen yang ada di dalam sistem yang disebut sebagai keluarga. Sesuai dengan penelitian (Dasaad, 2015) apabila salah satu komponen tidak menjalankan fungsinya dengan baik, bisa dikatakan suatu keluarga akan mengalami suatu goncangan dalam ketahanannya menahan ancaman dan rintangan yang datang. Memang, di dalam keluarga pasti akan ada ancaman-ancaman dan gangguan yang menggoyahkan ketahanan keluarga, maka yang harus dilakukan adalah penguatan secara akhlak, kesabaran dan sikap qanaah yang akan menghindarkan dari gangguan terhadap ketahanan keluarga Secara Praktis, Penguatan fungsi keluarga dalam mempertahankan keluarga bisa dimulai dari ranah Internal, yaitu penguatan secara spiritual, moral dan penanaman sikap qanaah, kemudian ranah Eksternal yaitu dengan pembiasaan terhadap lingkungan keluarga lain, sosial budaya, politik, sosial, politik, ekonomi. Karena manusia adalah zoon politicon (makhluk sosial yang tidak bisa berdiri sendiri).

\section{REFERENSI}

Abeng, T. (2006). Profesi Manajemen. Gramedia Pustaka Utama.

Allport, G. W., \& Ross, J. M. (1967). Personal religious orientation and prejudice. Journal of Personality and Social Psychology. https://doi.org/10.1037/h0021212

As'ad. (2013). Psikologi Industri. In Image Rochester NY.

Dasaad, D. (2015). Analisis Hubungan Kepemimpinan dan Kepuasan Kerja terhadap Kinerja Karyawan pada PT Adam Jaya. Jurnal Ilmiah Ekonomi Bisnis, 20(1).

Dekoulou, P., \& Trivellas, P. (2015). Measuring the Impact of Learning Organization on Job Satisfaction and Individual Performance in Greek Advertising Sector. Procedia - Social and Behavioral Sciences. https://doi.org/10.1016/j.sbspro.2015.01.1212

Kaparang, O. M. (2013). ANALISA GAYA HIDUP REMAJA DALAM MENGIMITASI BUDAYA POP KOREA MELALUI TELEVISI. Journal "Acta Diurna."

King, P. E., \& Boyatzis, C. J. (2016). Exploring adolescent spiritual and religious development: Current and future theoretical and empirical perspectives. In Applied Developmental Science. https://doi.org/10.1207/S1532480XADS0801_1

Lubis, A. (2018). Ketahanan Keluarga Dalam Perspektif Hukum Islam. Ketahanan Keluarga Dalam Perspektif Islam, 1-250.

Mas'ud, F. (2004). Survei Diagnosis Organisasional: Konsep \& Aplikasi. Program Magister Manajemen. Universitas Diponegoro. Badan Penerbit Univeritas Dipinogoro.

Mitroff, I., \& Denton, E. A. (2001). A Spiritual Audit of Corporate America: A Hard Look at Spirituality, Religion, and Values in the Workplace. Business and Society, 40(1), 148-150. http://fw8pk7vf4q.search.serialssolutions.com/?ctx_ver=Z39.88 2004\&ctx_enc=info:ofi/enc:UTF 8\&rfr_id=info:sid/ProQ\%3Aabiglobal\&rft_val_fmt=info:ofi/fmt:kev:mtx:journal\&rft.genre=unkno wn\&rft.jtitle $=$ Business + and + Society\&rft.atitle $=\mathrm{A}+$ Spiritual + Audit+of + Corpo

Purwanti, N. D., Sugiono, \& Hardiningtyas, D. (2014). Analisis Pengaruh Kualitas Pelayanan Dan Citra Perusahaan Terhadap Kepuasan Dan Loyalitas Pelanggan (Studi Kasus: PT.PLN (Persero) Rayon Malang Kota). Jurnal Rekayasa Dan Manajemen Sistem Industri, 3(2), 244-255. 
Purwo Saputro, E., \& Handayani, S. (2016). Pengaruh Nilai Hedonis terhadap Niat Belanja Online. Jurnal Eka Cida.

Riaz, M., Ahmad, N., Riaz, M., Murtaza, G., Khan, T., \& Firdous, H. (2016). Impact of Job Stress on Employee Job Satisfaction. International Review of Management and Business Research.

Salam, B. (2000). Etika Individual: Pola Dasar Filsafat Moral. In PT Rineka Cipta.

Sari, N. (2018). PENGARUH RELIGIUSITAS DAN STATUS SOSIAL EKONOMI ORANG TUA TERHADAP GAYA HIDUP HEDONISME PADA REMAJA. MOTIVA JURNAL PSIKOLOGI. https://doi.org/10.31293/mv.v1i1.3492

Singh, R., Kumar, N., \& Puri, S. (2017). Thought self-leadership strategies and sales performance: integrating selling skills and adaptive selling behavior as missing links. Journal of Business and Industrial Marketing. https://doi.org/10.1108/JBIM-06-2016-0127

Sudarsih, S. (2018). Konsep hedonisme epikuros dan situasi Indonesia masa kini. Humanika.

Sulistyo, A., \& Wijayanto, W. (2015). Prosiding Seminar Nasional Pendidikan Meningkatkan Kinerja Guru Ditinjau dari Kedisiplinan dan Motivasi Kerja Guru di SD Negeri X Kecamatan Tanggungharjo Kabupaten Grobogan. Prosiding Ilmu Pendidikann: Meretas Sukses Publikasi Ilmiah Bidang Pendidikan Jurnal Bereputasi.

Swastha, B., \& Irawan. (2005). Asas-Asas Marketing. Marketing Journal.

Trimartati, N. (2014). Studi Kasus Tentang Gaya Hidup Hedonisme Mahasiswa Bimbingan dan Konseling Angkatan 2011 Universitas Ahmad Dahlan. PSIKOPEDAGOGIA Jurnal Bimbingan Dan Konseling. https://doi.org/10.12928/psikopedagogia.v3i1.4462

Wheldon, P., \& Webley, S. (2013). Corporate Ethics Policies and Programmes: 2013 UK and Continental European Survey. Institute of Business Ethics. 